\title{
Designing a Pustekipad Computer Laboratory Loan Application for Learning ICT Subjects
}

\section{Rancangan Aplikasi Peminjaman Laboratorium Komputer Pustekipad Untuk Pembelajaran Mata Kuliah TIK}

\author{
Reza Syafrizal ${ }^{1 *}$, Ahmad Tabrani ${ }^{1}$
}

\begin{abstract}
This study explores the management system of the technology center and database laboratory which is far from being optimal to facilitate ICT courses. This study aims at developing an application used to facilitate ICT learning in order to optimize the computer laboratory use and make it more systematic. The method used in this research is a descriptive qualitative method. The data were collected through observation. The result of the study shows that the application which was developed could simplify the work of the users and administrators in the computer laboratory management system.
\end{abstract}

\section{Keywords}

Utilization of Komputer Laboratories, Loan Applications, ICT Learning

\begin{abstract}
Abstrak
Tulisan ini dilatarbelakangi oleh belum optimalnya pemanfaatan laboratorium komputer pustekipad (Pusat Teknologi Informasi dan Pangkalan Data) untuk pembelajaran mata kuliah TIK. Dari permasalahan tersebut maka penulis melakukan penelitian untuk membuat sebuah aplikasi peminjaman laboratorium komputer tersebut. Metode yang digunakan dalam penelitian ini menggunakan metode deskriptif kualitatif. Metode observasi juga digunakan dalam pembuatan tulisan ini. Hasil penelitian berupa aplikasi yang digunakan untuk memudahkan penggunaan laboratorium komputer pustekipad untuk pembelajaran TIK. Dosen dan sivitas akademika yang menjadi pengguna di dalam laboratorium ini dengan mudah melakukan peminjaman laboratorium dengan memanfaatkan aplikasi yang telah dibuat. Hal itu mempermudah pengguna dan administrator dalam pengelolaan laboratorium.
\end{abstract}

\section{Kata Kunci}

Pemanfaatan Laboratorium Komputer, Aplikasi Peminjaman Laboratorium, Pembelajaran TIK

${ }^{1}$ UIN Sultan Maulana Hasanuddin Banten

Jalan Jend. Sudirman No. 30, Kota Serang - Provinsi Banten

*reza.syafrizal@uinbanten.ac.id

Submitted : January 25, 2021. Accepted : February 14, 2021. Published : February 15, 2021. 


\section{PENDAHULUAN}

Dalam era globalisasi pada saat ini, perkembangan ilmu pengetahuan dan teknologi berkembang sangat pesat sehingga memudahkan kita dalam melakukan aktifitas. Salah satu teknologi yang bekembang pesat adalah teknologi komputer. Dengan teknologi komputer memungkinkan informasi dapat disampaikan dengan cepat dan mudah. Salah satunya dengan internet kita bisa mendapatkan informasi melalui web-web. Berkembangnya teknologi informasi dan komunikasi telah membuka kemungkinan-kemungkinan kegiatan yang sebelumnya sulit atau bahkan tidak bisa dilakukan, saat ini dengan mudah bisa dilakukan [1].

Dalam dunia pendidikan, diperlukannya reformasi yang berkaitan erat dengan sistem informasi tentang bagaimana dunia pendidikan berusaha menggunakan perangkat komputer, yang dapat diaplikasikan sebagai sarana komunikasi untuk meningkatkan kinerja dunia pendidikan secara signifikan. Manajemen menilai pendidikan sebagai penggerak pada sistem informasi manajemen pendidikan, sekaligus sistem informasi manajemen pendidikan sebagai penentu proses manajemen pendidikan. Meningkatnya ilmu pengetahuan dan teknologi terutama pada bidang komputerisasi telah menunjukkan bahwa perkembangan tersebut dapat membantu memecahkan masalah pada proses implementasi sistem informasi manajemen pendidikan [2]. Disamping itu sistem informasi semakin dibutuhkan oleh lembaga pendidikan, khususnya dalam meningkatkan kelancaran aliran informasi dalam lembaga pendidikan, kontrol kualitas, dan menciptakan aliansi atau kerjasama dengan pihak lain yang dapat meningkatkan kualitas nilai lembaga pendidikan tersebut [1].

Jumlah Lab komputer pada Unit Pustekipad (Pusat Teknologi Informasi dan Pangkalan Data) berjumlah 3 Lab, Lab A sejumlah 20 unit komputer, Lab B sejumlah 40 unit komputer dan Lab C sejumlah 20 Unit Komputer. Pemanfaatan lab komputer ini di gunakan oleh dosen dalam pembelajaran TIK. Permasalahan muncul ketika terjadinya bentrok dalam penggunaan Lab Pustekipad. Peminjaman Lab yang masih manual menjadi titik kunci permasalahannya. Tidak adanya konfirmasi antara peminjam dan pengelola lab menjadi isu permasalahan yang ada.

Pengembangan Sistem Informasi Peminjaman Laboratorium Pustekipad dibangun berbasiskan web ini, merupakan salah satu langkah mengatasi permasalahan tersebut. Dengan adanya Sistem Informasi Peminjaman Laboratorium, informasi mengenai peminjaman laboratorium beserta jadwalnya akan lebih terlihat sehingga pengguna yang membutuhkan tidak sulit dalam menyesuaikan jadwal. Pada sistem ini juga dapat melakukan proses peminjaman laboratorium. Berdasarkan hal di atas, maka penulis melakukan suatu penelitian untuk membangun sistem informasi peminjaman laboratorium Unit Pustekipad UIN Sultan Maulana Hasanuddin Banten.

Sistem didefinisikan sebagai sekumpulan komponen yang terdiri dari sub-sistem fisik dan non-fisik/logika yang saling berhubungan satu sama lainnya dan bekerja sama untuk mencapai suatu tujuan [3]. Gabungan kedua kata tersebut, sistem informasi dapat didefinisikan sebagai kumpulan elemen yang saling berhubungan satu sama lain yang membentuk satu kesatuan yang berfungsi untuk mengintegrasikan data, memproses dan menyimpan serta mendistribusikan informasi [4]. Laboratorium adalah tempat yang digunakan kegiatan percobaan atau penyelidikan dalam bidang ilmu tertentu seperti fisika, kimia, biologi dan sebagainya [5].

Dalam pengembangan penelitian ini beberapa acuan peneliti sebelumnya juga penulis gunakan terutama pengembangan aplikasi-aplikasi yang digunakan di kampus [6][7][8][9]

\section{METODE PENELITIAN}

Metode penelitian yang digunakan dalam tulisan ini adalah dengan metode kualitatif deskriptif dengan langkah awal yang dilakukan adalah survei permasalahan yang ada di 
lapangan, kemudian menentukan solusi yang tepat. Metode kualitatif deskriptif ini menjabarkan langkah-langkah yang dilakukan oleh untuk mengatasi permasalahan tersebut. Peneliti mencoba memberikan sebuah solusi dengan membangun sebuah aplikasi sebagai solusi dari belum optimalnya pemanfaatan laboratorium komputer untuk pembelajaran mata kuliah TIK.

\section{HASIL DAN PEMBAHASAN}

\section{Analisa Dan Perancangannya}

Kegiatan pertama yang dilakukan adalah menyusun mekanisme standar operasional prosedur peminjaman laboratorium komputer. Setelah observasi lapangan, maka penulis melakukan koordinasi dengan pimpinan unit tentang penyusunan standar operasional prosedur sebuah aplikasi untuk peminjaman laboratorium Pustekipad. Menyampaikan konsep rancangan apa saja yang akan dilakukan kepada pimpinan unit kerja Pustekipad. Menyusun mekanisme standar operasional prosedur peminjaman lab komputer pustekipad. Seperti pada Tabel 1.

Tabel 1. Alur SOP Mekanisme Pelayanan Administrasi Peminjaman / Penggunaan Lab Komputer

\begin{tabular}{|c|c|c|c|c|c|c|c|c|}
\hline \multirow{2}{*}{ NO } & \multirow{2}{*}{ Uraian Prosedur } & \multicolumn{3}{|c|}{ Pelaksana } & \multicolumn{3}{|c|}{ Mutu Baku } & \multirow{2}{*}{ Ket } \\
\hline & & Pengguna & Operator & $\begin{array}{l}\text { Kepala Unit } \\
\text { Pustekipad }\end{array}$ & $\begin{array}{l}\text { Persyaratan / } \\
\text { perlengkapan }\end{array}$ & Waktu & Output & \\
\hline 1 & $\begin{array}{l}\text { Pengguna membuka aplikasi sistem } \\
\text { informasi penggunaan / peminjaman } \\
\text { lab komputer pustekipad (e-pinlab) }\end{array}$ & 1 & & & $\begin{array}{l}\text { Dosen dan Staff } \\
\text { Akademik }\end{array}$ & $\begin{array}{l}\text { Setiap Hari } \\
\text { Kerja }\end{array}$ & $\begin{array}{c}\text { Akses } \\
\text { Aplikasi }\end{array}$ & \\
\hline 2 & $\begin{array}{l}\text { Jika pengguna sudah memiliki } \\
\text { account aplikasi, maka pengguna } \\
\text { melakukan login ke sistem aplikasi e- } \\
\text { pinlab. Jika belum memiliki account, } \\
\text { pengguna melakukan registrasi } \\
\text { account baru. }\end{array}$ & Tidak & & & User Account & $\begin{array}{l}\text { Setiap Hari } \\
\text { Kerja }\end{array}$ & $\begin{array}{l}\text { Akses } \\
\text { Aplikasi }\end{array}$ & \\
\hline 3 & $\begin{array}{l}\text { Pengguna melakukan registrasi di } \\
\text { aplikasi sistem informasi penggunaan } \\
/ \text { peminjaman lab komputer } \\
\text { pustekipad (e-pinlab) }\end{array}$ & $\frac{\downarrow}{3}$ & & & User Account & 5 Menit & $\begin{array}{l}\text { Akses } \\
\text { Aplikasi }\end{array}$ & \\
\hline 4 & $\begin{array}{l}\text { Jika Registrasi pengguna baru di } \\
\text { approve oleh operator }\end{array}$ & & & & Approve Operator & $\begin{array}{l}\text { Setiap Hari } \\
\text { Kerja }\end{array}$ & $\begin{array}{l}\text { Permohonan } \\
\text { user account }\end{array}$ & \\
\hline 5 & $\begin{array}{l}\text { Pengguna melakukan login dan } \\
\text { mengisi data dan jadwal penggunaan } \\
\text { lab di sistem aplikasi informasi } \\
\text { penggunaan / peminjaman lab } \\
\text { komputer pustekipad (e-pinlab) }\end{array}$ & 5 & Ya & & User Account & $\begin{array}{l}\text { Setiap Hari } \\
\text { Kerja }\end{array}$ & $\begin{array}{c}\text { Akses } \\
\text { Aplikasi }\end{array}$ & \\
\hline 6 & $\begin{array}{l}\text { User mengupload surat pengajuan ke } \\
\text { dalam sistem }\end{array}$ & 6 & & & Form Peminjaman & 1 Menit & $\begin{array}{c}\text { Form } \\
\text { Peminjaman }\end{array}$ & \\
\hline 7 & $\begin{array}{l}\text { Jika Persetujuan Pengajuan } \\
\text { penggunaan lab komputer di terima }\end{array}$ & & & & $\begin{array}{l}\text { Approve Kepala } \\
\text { Unit }\end{array}$ & $\begin{array}{l}\text { Setiap Hari } \\
\text { Kerja }\end{array}$ & $\begin{array}{l}\text { Permohonan } \\
\text { di terima }\end{array}$ & \\
\hline 8 & $\begin{array}{l}\text { Pengguna menggunakan lab } \\
\text { komputer }\end{array}$ & 8 & & Ya & $\begin{array}{l}\text { Pengajuan } \\
\text { Diterima }\end{array}$ & $\begin{array}{l}\text { Setiap Hari } \\
\text { Kerja }\end{array}$ & $\begin{array}{l}\text { Penggunaan } \\
\text { Lab }\end{array}$ & \\
\hline 9 & Selesail & $\downarrow$ & & & Selesai & Selesai & Selesai & \\
\hline
\end{tabular}

Kegiatan kedua Membuat alir peminjaman lab. komputer atau flowchart Gambar 1. Pengertian dari flowchart itu sendiri adalah menggambarkan, menyederhanakan rangkaian proses atau prosedur sehingga mudah dipahami dan mudah dilihat berdasarkan urutan langkah dari suatu proses. Dengan pengungkapan yang jelas dalam model Flowchart, maka pembuatan sebuah aplikasi akan menjadi lebih mudah. Membuat konsep inti untuk bagan alir yang mudah di baca Dengan cara mencari inti atau pokok penting dari sebuah tahapan atau proses sebuah aktivitas memudahkan dalam menyusun sebuah flowchart atau diagaram alir. Kedua, Menyusun dan merancang bagan alir atau flowchart dalam bentuk diagram. Dalam 
proses pembuatan flowchart, penulis membuat nya dari konsep inti yang sudah dibuat sebelumnya, disusun dan dirancang sehingga menghasilkan sebuah flowchart peminjaman lab komputer secara efektif dan efisien.

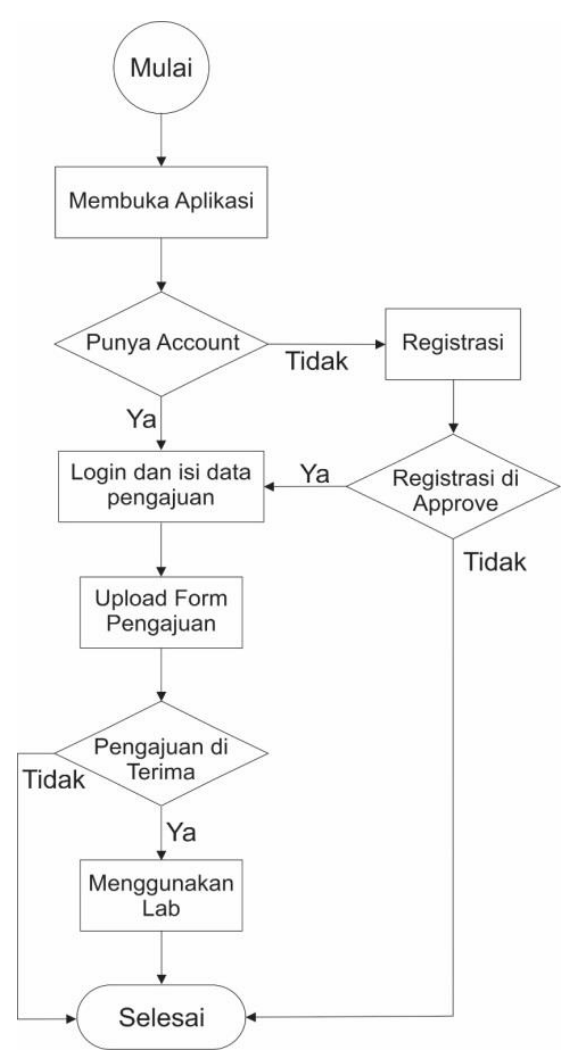

Gambar 1. Flowchart alur Penggunaan atau Peminjaman Laboratorium Komputer

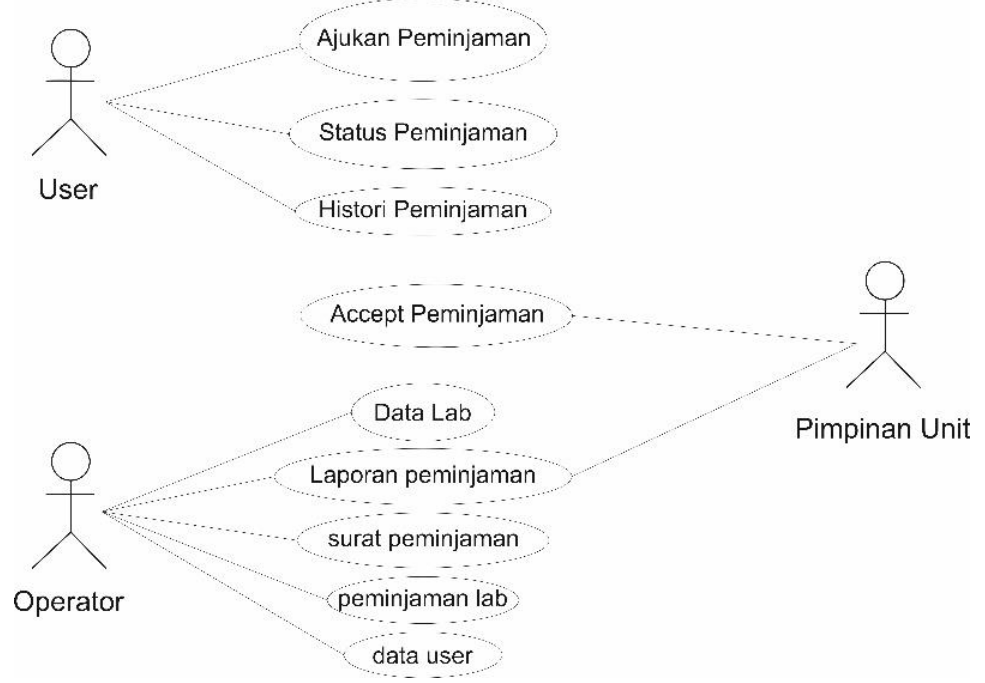

Gambar 2. Use case diagram sistem usulan

Menulis konsep intinya untuk bagan alir (flowchart)

1. Pengguna Membuka aplikasi sistem informasi Penggunaan/peminjaman Lab Komputer

2. Jika belum memiliki account, bisa melakukan registrasi. Jika sudah ada bisa login

3. Registrasi di approve oleh operator

4. Pengguna login dan mengisi data dan jadwal penggunaan lab di sistem aplikasi 
5. User mengupload surat pengajuan ke dalam system

6. Persetujuan Pengajuan penggunaan lab komputer di terima

7. User menggunakan lab komputer

8. Selesai

Kegiatan ketiga Menyusun form surat pengajuan peminjaman ruang laboratorium komputer pustekipad. Kegiatan penyusunan form surat pengajuan peminjaman ruang laboratorium komputer pustekipad ini dilakukan agar form peminjaman tidak berbeda-beda antara satu dengan yang lainnya. Sehingga tidak terjadi kesalahan dalam proses pengajuan form peminjaman. Pengguna bisa mendownload form pengajuan yang ada di dalam aplikasi tersebut.

Kegiatan keempat Membuat aplikasi peminjaman lab. komputer pustekipad. Untuk memudahkan penamaan maka penulis menggunakan nama e-Pinlab untuk aplikasi yang dikembangkan. Usecase diagram yang dikembangkan seperti tertampil pada gambar 2 . Aplikasi sistem informasi peminjaman lab ini dibuat dengan pemrograman berbasis web php 5 dan database $M y S Q L$. Tampilan implementasi database dapat dilihat pada gambar 3.

Beberapa tangkapan layar aplikasi yang sudah dikembangkan ditampilkan selanjutnya. Tampilan halaman depan dapat dilihat pada gambar 4. Tampilan halaman Registrasi User Baru pada gambar 5. Tampilan Halaman pengajuan peminjaman Lab Komputer pada gambar 6. Tampilan halaman Pimpinan Unit untuk menyetujui pengajuan peminjaman pada gambar 7. Dan gambar 8 adalah tampilan halaman pengguna jika pengajuan peminjaman telah di setujui.

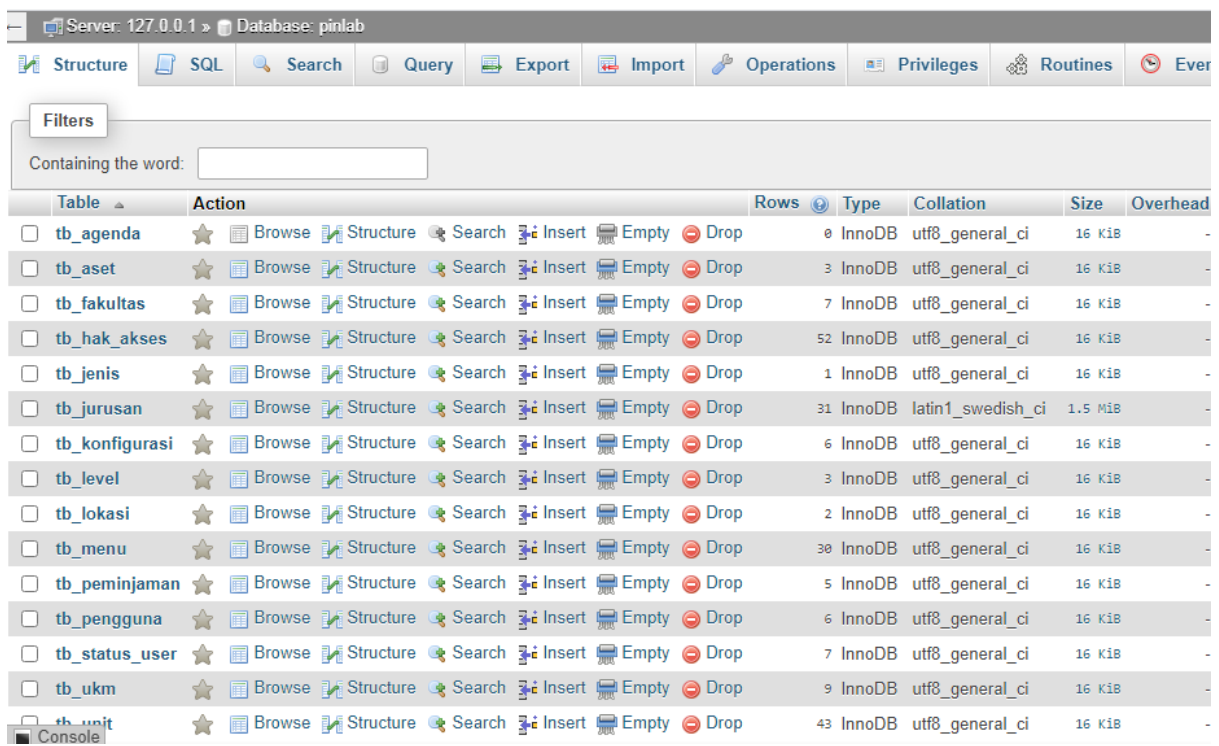

Gambar 3. Hasil implementasi database
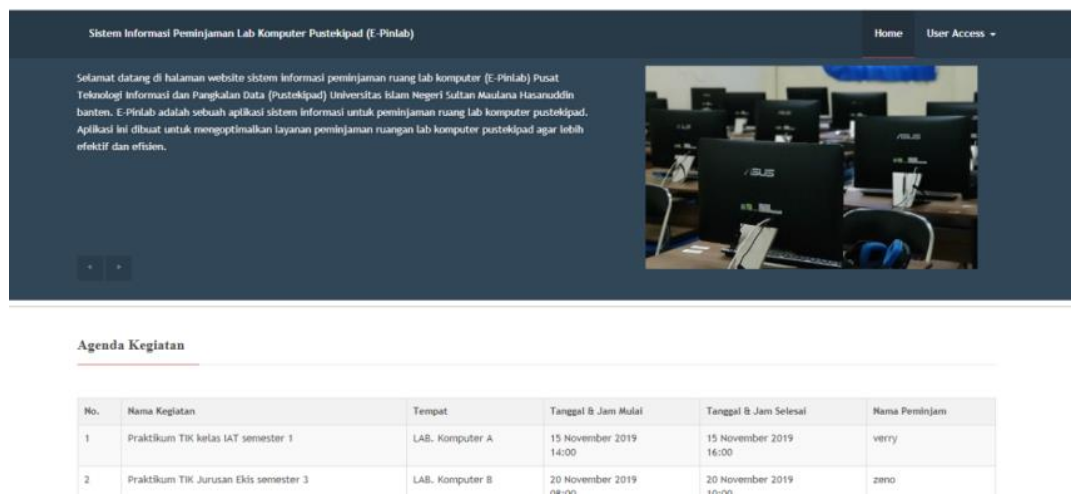

Gambar 4. Tampilan halaman depan Aplikasi E-Pinlab 




Gambar 5. Tampilan halaman Registrasi User Baru

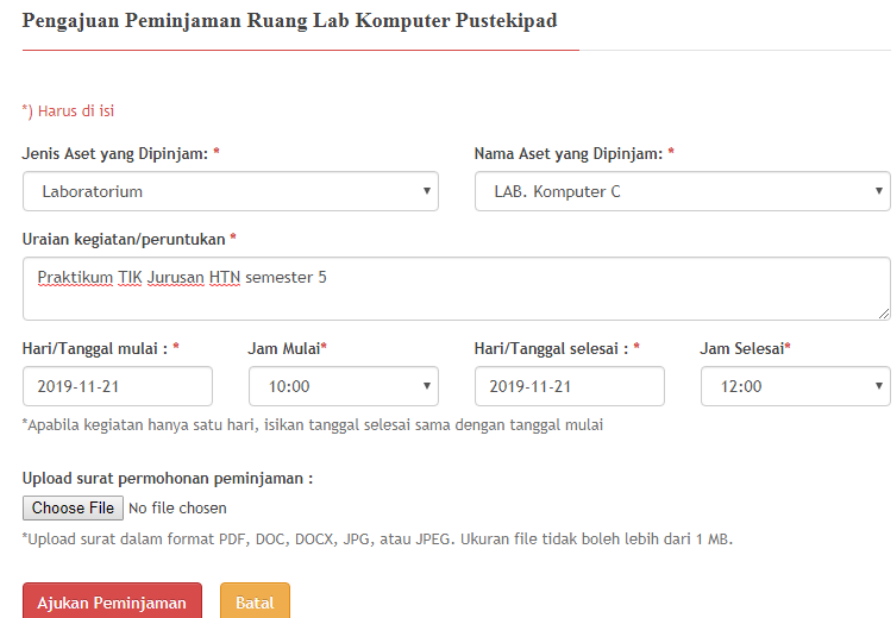

Gambar 6. Tampilan Halaman pengajuan peminjaman Lab Komputer

Data Pengajuan Peminjaman Tempat

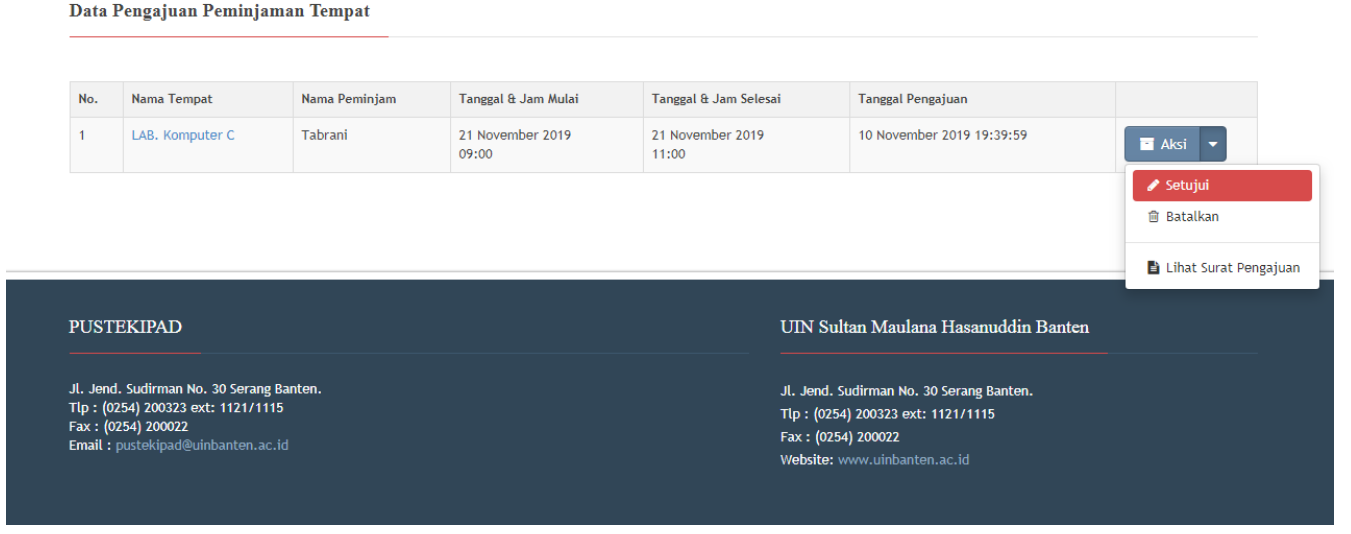

Gambar 7. Tampilan halaman Pimpinan Unit untuk menyetujui pengajuan peminjaman 
Data Pengajuan Peminjaman

\begin{tabular}{|l|l|l|l|l|l|l|l|}
\hline No. & Nama Aset & Jenis & Tanggal \& Jam Mulai & Tanggal \& Jam Selesai & Tanggal Pengajuan & Status Pengajuan \\
\hline 1 & LAB. Komputer A & Laboratorium & $\begin{array}{l}01 \text { November } 2019 \\
10: 00\end{array}$ & $\begin{array}{l}01 \text { November } 2019 \\
12: 00\end{array}$ & 31 Oktober 2019 08:06:12 & Disetujui \\
\hline 2 & LAB. Komputer C & Laboratorium & $\begin{array}{l}21 \text { November 2019 } \\
09: 00\end{array}$ & $\begin{array}{l}21 \text { November } 2019 \\
11: 00\end{array}$ & 10 November 2019 19:39:59 & Disetujui \\
\hline
\end{tabular}

Gambar 8. Tampilan halaman pengguna jika pengajuan peminjaman telah di setujui

Setelah aplikasi berhasil dikembangkan, selanjutnya masuk ke kegiatan kelima, pada kegiatan ini penulis melaksanakan Sosialisasi aplikasi peminjaman lab komputer (e-pinlab) dengan media cetak atau poster yang dipublish di papan informasi Pusat Teknologi Informasi dan Pangkalan Data (gambar 9).

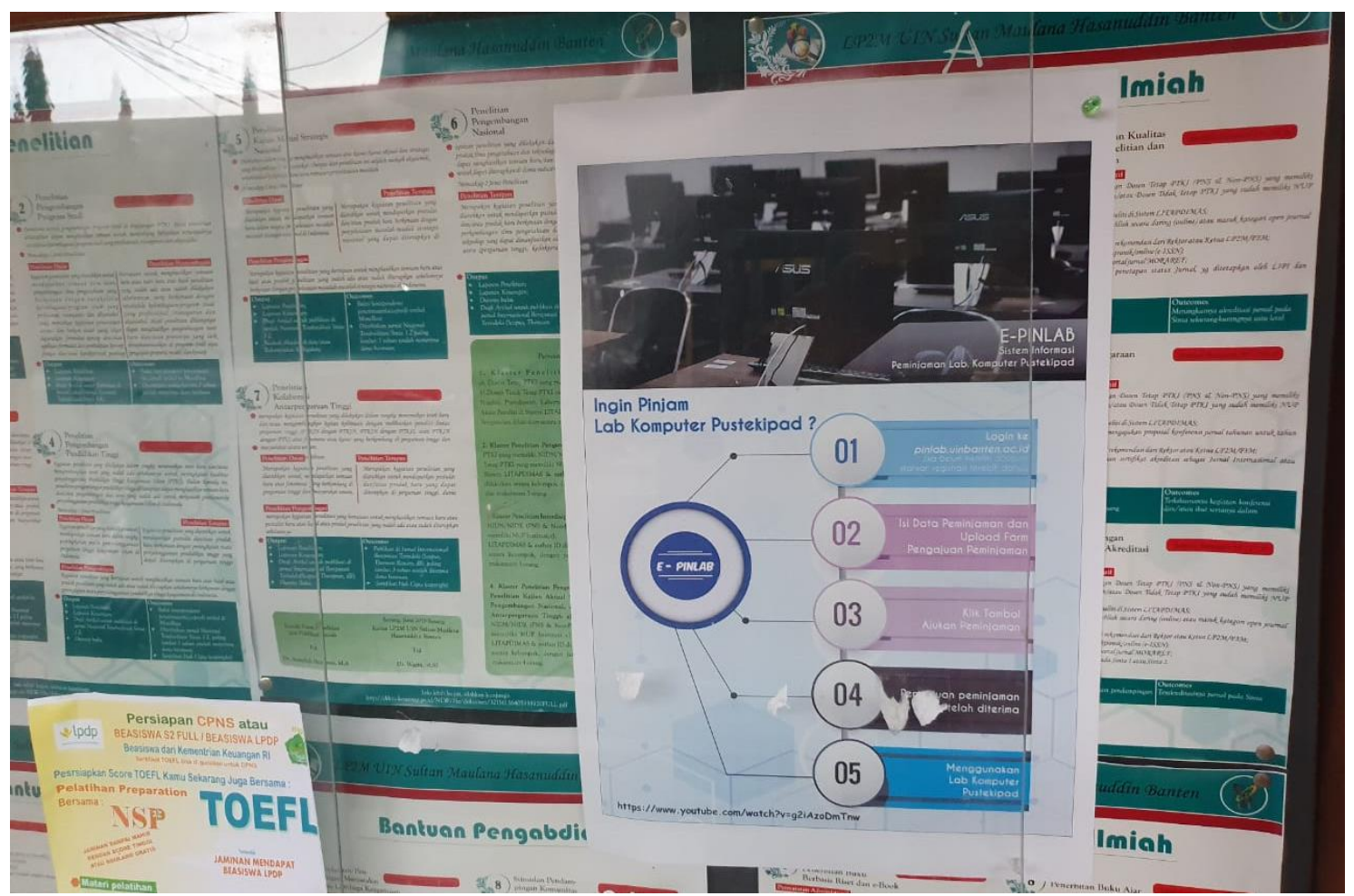

Gambar 9. Foto kegiatan sosialisasi aplikasi peminjaman laboratorium komputer pustekipad dengan media poster. 


\section{KESIMPULAN}

Dari pembahasan diatas dapat disimpulkan bahwa telah berhasil dikembangkan sistem informasi peminjaman laboratorium Unit Pustekipad yang dapat menampilkan jadwal peminjaman laboratorium. Dengan adanya Aplikasi Peminjaman Lab Komputer Unit Pustekipad tidak ada lagi bentrok jadwal dalam peminjaman atau penggunaan lab komputer unit Pustekipad.

\section{DAFTAR RUJUKAN}

[1] Afilia, Rina. Tingkat Kepuasan Orang Tua Dalam Akses Sistem Informasi Manajemen Rapot Online Di SD Islam Maryam Surabaya. Skripsi. Universitas Islam Negeri Sunan Ampel Surabaya. 2016

[2] Wahyudi, Apri., Sowiyah dan Ambarita, Alben. Implementasi Sistem Informasi Manajemen Akademik Berbasis Web. Jurnal. Universitas Lampung. 2015

[3] Prahasta, Eddy. Sistem Informasi Geografis: Konsep-Konsep Dasar (Perspektif Geodesi \& Geomatika). Informatika. Bandung. 2014.

[4] Oetomo, Budi Sutedjo. Perencanaan \& Pembangunan Sistem Informasi. Andi. Yogyakarta. 2002

[5] Rahmiyati, Sri. Keefektifan Pemanfaatan Laboratorium di Madrasah Aliyah Yogyakarta. Jurnal. Penelitian dan Evaluasi Pendidikan. 2008.

[6] Rasyidah, R., Azmi, M., \& Wicaksana, W. (2020). A Web-Based Information System for Student Affairs Letter Management : Design and Implementation in Padang State Polytechnics. MOTIVECTION : Journal of Mechanical, Electrical and Industrial Engineering, 2(3), 51-68. https://doi.org/10.46574/motivection.v2i3.75

[7] Renny Puspita Sari, Ibnur Rusi, and Tasha Safira Putri, "Sistem Informasi Peminjaman Ruangan Fakultas MIPA Universitas Tanjungpura”, SISFOTEK, vol. 4, no. 1, pp. 250 - 256, Aug. 2020.

[8] Prasetyo, Rizky Ridho, and Rio Wirawan. "Perancangan Sistem Informasi Peminjaman Ruangan Berbasis Web Pada Universitas Pembangunan Nasional "Veteran" Jakarta." SEINASI-KESI 1.1 (2018): 63-68.

[9] Choiriyah, Ervinnia Hikma, and Agung Handayanto. "SISTEM INFORMASI PEMINJAMAN RUANGAN BERBASIS WEBSITE DI UNIVERSITAS PGRI SEMARANG." Science and Engineering National Seminar. Vol. 5. No. 1. 2020. 